\title{
Giftgrubeite, $\mathrm{CaMn}_{2} \mathrm{Ca}_{2}\left(\mathrm{AsO}_{4}\right)_{2}\left(\mathrm{AsO}_{3} \mathrm{OH}\right)_{2} \cdot 4 \mathrm{H}_{2} \mathrm{O}$, a new member of the hureaulite group from Sainte-Marie-aux-Mines, Haut-Rhin Department, Vosges, France
}

\author{
Nicolas MEISSER ${ }^{1 *}$, Jakub PLÁŠIL², Thierry BRUNSPERGER ${ }^{3}$, Cédric LHEUR ${ }^{4}$, Radek ŠKODA ${ }^{5}$ \\ ${ }^{1}$ Musée cantonal de géologie, Université de Lausanne, Anthropole, Dorigny, CH-1015 Lausanne, Switzerland; nicolas.meisser@unil.ch \\ ${ }^{2}$ Institute of Physics, Academy of Sciences of the Czech Republic v.v.i, Na Slovance 2, 18221 Prague 8, Czech Republic \\ 322 route de Wintzenheim, 68000 Colmar, France \\ ${ }^{4} 1$ rue du St Laurent, 54280 Seichamps, France \\ ${ }^{5}$ Department of Geological Sciences, Faculty of Science, Masaryk University, Kotlářrská 2, 61137 Brno, Czech Republic \\ ${ }^{*}$ Corresponding author
}

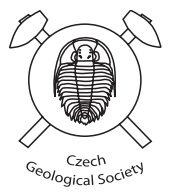

Giftgrubeite, ideally $\mathrm{CaMn}_{2} \mathrm{Ca}_{2}\left(\mathrm{AsO}_{4}\right)_{2}\left(\mathrm{AsO}_{3} \mathrm{OH}\right)_{2} \cdot 4 \mathrm{H}_{2} \mathrm{O}$, is a new mineral occurring at the Giftgrube Mine, St Jacques vein, Rauenthal, Sainte-Marie-aux-Mines, Haut-Rhin Department, Grand Est, France and named after the type-locality. Giftgrubeite is mostly associated with Mn-bearing calcite, native arsenic, löllingite, and picropharmacolite. It is a recent secondary mineral, formed by alteration of the arsenical vein minerals after mining. Giftgrubeite occurs in colorless, rarely pearl white to pale yellow rosettes of brittle tabular crystals flattened on $\left\{\begin{array}{llll}1 & 0 & 0\end{array}\right\}$ and up to $0.2 \mathrm{~mm}$ in size. Hardness (Mohs) is $3 \frac{1}{2}, D_{\text {meas }}$ is $3.23(2) \mathrm{g} \cdot \mathrm{cm}^{-3}, D_{\text {calc }}$ is $3.24 \mathrm{~g} \cdot \mathrm{cm}^{-3}$. The new mineral is biaxial negative without pleochroism. Measured $2 \mathrm{~V}$ angle is $\sim 72^{\circ}$ and calculated $2 \mathrm{~V}$ angle is $75.1^{\circ}$; the refractive indices measured in white light are: $\alpha=1.630(2), \beta=1.640(2)$ and $\gamma=1.646(2)$. The most prominent Raman bands are at 902, 885, 864, 851, 824, 797 and $759 \mathrm{~cm}^{-1}$. The empirical chemical formula is $\left(\mathrm{Ca}_{3.04} \mathrm{Mn}_{1.30} \mathrm{Mg}_{0.38} \mathrm{Fe}_{0.28}\right)_{\Sigma 5.00}\left(\mathrm{AsO}_{4}\right)_{1.99}\left(\mathrm{AsO}_{3} \mathrm{OH}\right)_{2} \cdot 4 \mathrm{H}_{2} \mathrm{O}$. Giftgrubeite is monoclinic, $C 2 / c, Z=4$, with $a=18.495(7) \AA, b=9.475(4) \AA, c=9.986(4) \AA, \beta=96.79(3)^{\circ}$ and $V=1737.7(12) \AA^{3}$. The six strongest lines in the X-ray powder diffraction pattern are $[d$ in $\AA(I)(h k l)]: 3.33(100)(-222), 3.18(80)(22$ 2), $2.414(60)(711), 4.80(50)(-311), 4.65(50)(-202)$ and $3.05(50)\left(\begin{array}{lll}1 & 1 & 3\end{array}\right)$. The structure of giftgrubeite was solved from the crystal retrieved from the type specimen by the charge-flipping algorithm. Giftgrubeite contains a well-known structure type parent to the hureaulite group of minerals, which is based upon an octahedral edge-sharing pentamers of $M^{2+}$-polyhedra, pentamers linked into a loose framework by sharing corners with octahedra in adjacent pentamers and further by $\mathrm{AsO}_{4}$ and $\mathrm{AsO}_{3} \mathrm{OH}$ tetrahedra. There are three distinct octahedral sites: $M 1, M 2$, and $M 3$. In the case of giftgrubeite, two of the $M$ sites were found to be fully occupied by Ca; namely $M 1$ and $M 3$. The $M 2$ site was then found to contain $\mathrm{Mg}$ besides dominant $\mathrm{Mn}$. Considering the refined site occupancies, the structural formula for giftgrubeite is $\mathrm{Ca}_{3} \mathrm{Mn}_{1.30} \mathrm{Mg}_{0.70}\left(\mathrm{AsO}_{4}\right)_{2}\left(\mathrm{AsO}_{3} \mathrm{OH}\right)_{2}\left(\mathrm{H}_{2} \mathrm{O}\right)_{4}$. Giftgrubeite is an ordered intermediate member between villyaellenite, $\mathrm{MnMn}_{2} \mathrm{Ca}_{2}\left(\mathrm{AsO}_{3} \mathrm{OH}\right)_{2}\left(\mathrm{AsO}_{4}\right)_{2} \cdot 4 \mathrm{H}_{2} \mathrm{O}$ and sainfeldite, $\mathrm{CaCa}_{2} \mathrm{Ca}_{2}\left(\mathrm{AsO}_{4}\right)_{2}\left(\mathrm{AsO}_{3} \mathrm{OH}\right)_{2} \cdot 4 \mathrm{H}_{2} \mathrm{O}$.

Keywords: giftgrubeite, arsenate, new mineral, hureaulite group, crystal structure, Sainte-Marie-aux-Mines

Received: 14 June 2018; accepted: 6 December 2018; handling editor: F. Laufek

The online version of this article (doi: 10.3190/jgeosci.276) contains supplementary electronic material.

\section{Introduction}

The Sainte-Marie-aux-Mines ore district, with its long mining and mineralogical history, is famous due to the unusual occurrence of $\mathrm{Ca}$ - and $\mathrm{Mg}$-bearing arsenates. The St. Jacques vein, locally enriched by native arsenic and $\mathrm{Fe}-\mathrm{Ni}-\mathrm{Co}$ arsenides, is the type-locality for several Ca-bearing arsenates: ferrarisite (Bari et al. 1980a), fluckite (Bari et al. 1980b), mcnearite (Sarp et al. 1981), phaunouxite (Bari et al. 1982), rauenthalite (Pierrot 1964), sainfeldite (Pierrot 1964), villyaellenite (Sarp 1984), weilite (Herpin and Pierrot 1963) and giftgrubeite (this study).
Giftgrubeite is named after the type locality, the Giftgrube Mine close to Sainte-Marie-aux-Mines (Vosges, France). Name "Giftgrube" originates from the German "Gift" = poisonous, and "Grube" = mine; the mine was in operation namely for mining silver, copper and native arsenic. The mineral and its name were approved by Commission on New Minerals, Nomenclature and Classification (CNMNC) in April 2017 (IMA2016-102) (Hålenius et al. 2017). One holotype and one part of them, defined as cotype, specimens are deposited in the mineral collection of the Musée cantonal de géologie, University of Lausanne, Anthropole, Dorigny, CH-1015 Lausanne, Switzerland, catalog numbers MGL $\mathrm{n}^{\circ} 080133$ and 080134 , respectively. 


\section{Occurrence}

The new mineral was found in an old stope on the St. Jacques vein, in the Giftgrube Mine, the Rauenthal Valley, Sainte-Marie-aux-Mines, Haut-Rhin Department, Grand Est, France.

Giftgrubeite is a supergene mineral, formed by alteration of the As-bearing hypogene minerals and its formation is connected with the post-mining alteration processes. The Giftgrube Mine was first mined for $\mathrm{Ag}$ (and $\mathrm{Cu}$ ) during the $16-17^{\text {th }}$ century. Some galleries were reopened later, especially during the $18^{\text {th }}$ century. Arsenic has been exploited only slightly during early $20^{\text {th }}$ century at the same time as Gabe Gottes Mine (1932-1940) in the same vein. That is why there are loose pieces of native arsenic on the ground and walls of the mine (left by miners), in old works. The associated minerals occurring with giftgrubeite are gangue quartz and multi-stage deposition carbonates, $\mathrm{Mn}-\mathrm{Fe}$-bearing calcite (up to $5 \mathrm{~mol} . \% \mathrm{MnCO}_{3}$ and up to $2 \mathrm{~mol}$. \% $\mathrm{FeCO}_{3}$ ) and $\mathrm{Fe}-\mathrm{Mn}$-bearing dolomite, as well as native
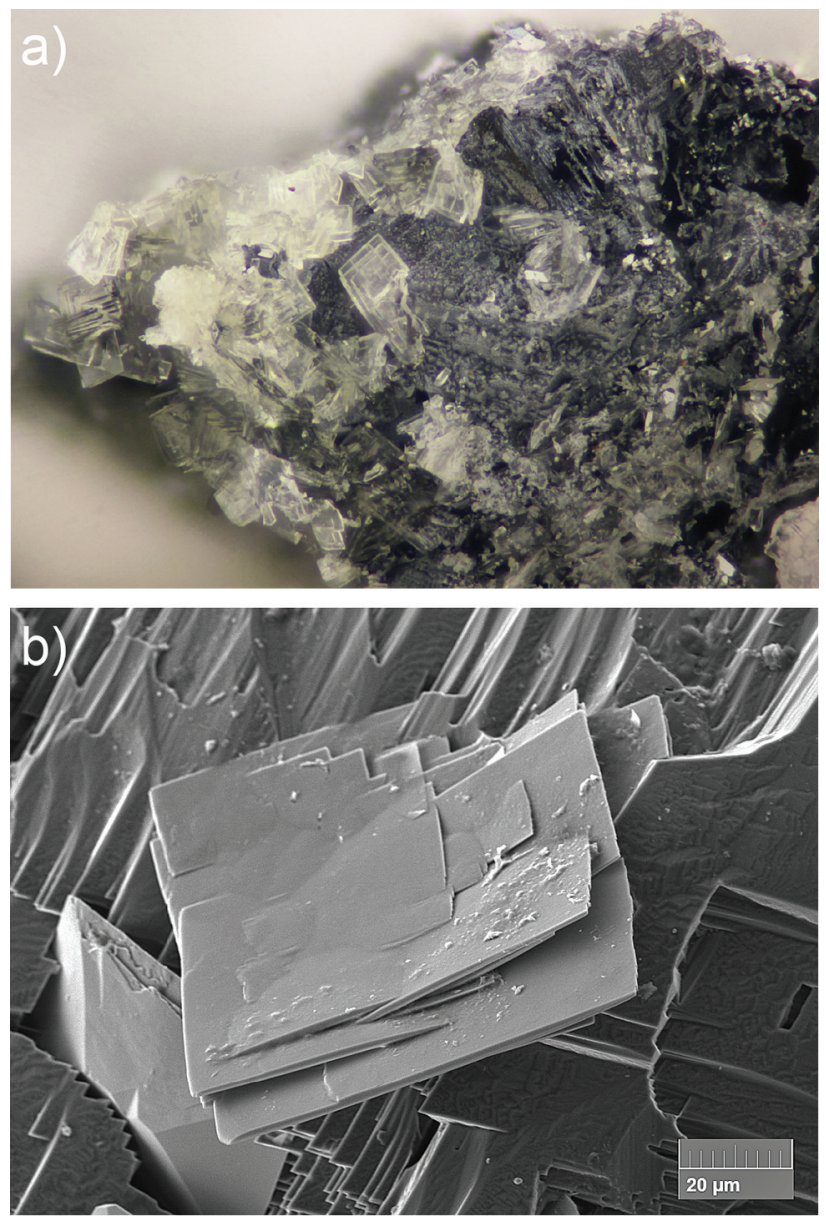

Fig. 1a - Tabular crystals of giftgrubeite on black, tarnished native arsenic affected by alteration. Horizontal width of photograph is $1.6 \mathrm{~mm}$. b - Flattened $\{100\}$ crystals aggregate of giftgrubeite (SEM image). arsenic, löllingite, tetrahedrite, skutterudite, and chalcopyrite. Associated oxidized post-mining minerals are arsenolite, picropharmacolite, pharmacolite \pm haidingerite, chongite and scorodite.

\section{Physical and optical properties}

Giftgrubeite occurs in crystals forming rosette-like aggregates having up to $0.2 \mathrm{~mm}$ across (Fig 1a). Crystals are flattened $\{100\}$ (Fig 1b), with following crystal forms (by decreasing importance): $\{100\},\{001\},\{110\}$. Crystals are transparent with a vitreous luster. The mineral has a white streak. It is non-fluorescent under both long- and short-wave UV. The Mohs hardness is about $3 \frac{1}{2}$. Crystals are brittle without visible cleavage and have a curved fracture. The density was measured by floatation of crystals in diiodomethane/1-chloronaph-

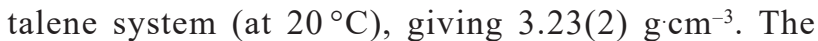
calculated density is $3.24 \mathrm{~g} \mathrm{~cm}^{-3}$ based on the empirical formula.

Optically, giftgrubeite is biaxial (-), with $\alpha=1.630(2)$, $\beta=1.640(2), \gamma=1.646(2)$ (measured in white light at $22^{\circ} \mathrm{C}$, with refractive index liquids controlled with a Leitz-Jelley micro-refractometer after measurements). The measured $2 V$ is $\sim 72^{\circ}$; the calculated $2 V$ is $75.1^{\circ}$. No pleochroism was observed.

\section{Chemical composition}

A crystal aggregate of giftgrubeite was analyzed (Tab. 1) using a Cameca SX100 electron microprobe (Masaryk University, Brno), operating in WDS mode with an accelerating voltage of $15 \mathrm{kV}$, beam current of $10 \mathrm{nA}$, and a $8 \mu \mathrm{m}$ beam diameter. The following $\mathrm{X}$-ray lines (standards) were used: $K_{\alpha}$ lines: $\mathrm{Mg}$ (diopside), Ca (wollastonite), $\mathrm{Mn}$ (rhodonite), Fe (almandine); $L_{\alpha}$ line: As (lammerite, $\left.\mathrm{Cu}_{3}\left(\mathrm{AsO}_{4}\right)_{2}\right)$. Other likely elements, such as $\mathrm{Si}, \mathrm{Al}, \mathrm{S}, \mathrm{P}, \mathrm{K}, \mathrm{V}$, and $\mathrm{F}$ were also sought, but their contents were below the detection limits $(\sim 0.05-0.15$ wt. \% with the analytical conditions used). The counting times were 10 or $20 \mathrm{~s}$ on peak and half of this on each background. The raw data were reduced using the $X-\varphi$ matrix correction routine (Merlet 1994). Because insufficient material was available for a direct determination of $\mathrm{H}_{2} \mathrm{O}$, the amount of water was calculated on the basis of charge balance and $\mathrm{O}=19 a p f u$, obtained by the crystal structure analysis.

The empirical formula is: $\left(\mathrm{Ca}_{3.04} \mathrm{Mn}_{1.30} \mathrm{Mg}_{0.38} \mathrm{Fe}_{0.28}\right)_{5.00}$ $\left(\mathrm{AsO}_{4}\right)_{1.99}\left(\mathrm{AsO}_{3} \mathrm{OH}\right)_{2} \cdot 4 \mathrm{H}_{2} \mathrm{O}$ and the simplified structural formula is $\mathrm{Ca}_{3} \mathrm{Mn}_{2}\left(\mathrm{AsO}_{4}\right)_{2}\left(\mathrm{AsO}_{3} \mathrm{OH}\right)_{2} \cdot 4 \mathrm{H}_{2} \mathrm{O}$, which requires $\mathrm{CaO} 19.57, \mathrm{Mn} 16.50, \mathrm{As}_{2} \mathrm{O}_{5} 53.46, \mathrm{H}_{2} \mathrm{O} 10.48$, total 100 wt. $\%$. 
The Gladstone-Dale compatibility $1-(\mathrm{Kp} /$ $\mathrm{Kc}$ ) for the empirical formula, is 0.011 in the range of excellent.

\section{Raman spectroscopy}

Raman spectrum of giftgrubeite (Fig. 2) was collected on Jobin-Yvon Labram HR, using a grid of 600 lines/mm, 100× objective lens and utilizing $633 \mathrm{~nm}$ laser. Spectral calibration was done on Ne-emission lines using the low-pressure Ne-discharge lamp. Raman spectrum of giftgrubeite (Fig. 2) is dominated by the stretching vibrations of $\mathrm{AsO}_{4}$ and $\mathrm{AsO}_{3}(\mathrm{OH})$ groups, respectively. The most prominent bands at $902,885,864,851,824,797$ and $759 \mathrm{~cm}^{-1}$ are attributed to overlapping $v_{3}$ antisymmetric and the $v_{1}$ symmetric As-O vibrations of the $\mathrm{AsO}_{4}$ and $\mathrm{AsO}_{3}(\mathrm{OH})$ groups; the bands of the lower energy can be assigned more favorably to the protonated $\mathrm{AsO}_{3}(\mathrm{OH})$. A weak shoulder at $696 \mathrm{~cm}^{-1}$ may be related to the out-of-plane bending vibration of As-OH. Sharp bands of the medium intensity at 433, 384, 359 and $342 \mathrm{~cm}^{-1}$ are related to the $v_{4}(\delta) \mathrm{O}-\mathrm{As}-\mathrm{O}$ and $v_{2}(\delta) \mathrm{O}-\mathrm{As}-\mathrm{O}$ bending vibrations. The bands at the lowest energies are related to the lattice modes. The broad bands of the low intensity in the range $2798-3448 \mathrm{~cm}^{-1}$ are attributed to the $v \mathrm{O}-\mathrm{H}$ vibrations of the hydrogen-bonded water molecules. The bands at 2300-2500 $\mathrm{cm}^{-1}$ most probably reflect organic impurities due to resin and glue to which the examined crystals were mounted.

\section{Powder X-ray diffraction (XRD)}

Powder XRD data were collected using a Gandolfi Camera (114.6 mm diameter; $\mathrm{Cu} K_{\alpha} / \mathrm{Ni}$-filtered; $\mathrm{Si}$ as external standard) and are given in Tab. 2. Unit-cell parameters refined from the powder data using the program UNITCELL (Holland and Redfern 1997) are as follows: $a=$ 18.67(2) $\AA, b=9.62(1) \AA, c=10.09(1) \AA, \beta=96.59(6)^{\circ}$, $V=1800(5) \AA^{3}, Z=4$.

\section{Single-crystal X-ray diffraction}

\subsection{Experiment and the refinement}

A single-crystal extracted from the type specimen was used for the single-crystal X-ray study on a Rigaku SuperNova diffractometer with mirror-monochromatized $\operatorname{Mo} K_{\alpha}$ radiation $(\lambda=0.71073 \AA)$ from a microfocus X-ray source detected by Atlas S2 CCD detector. Crystallo-

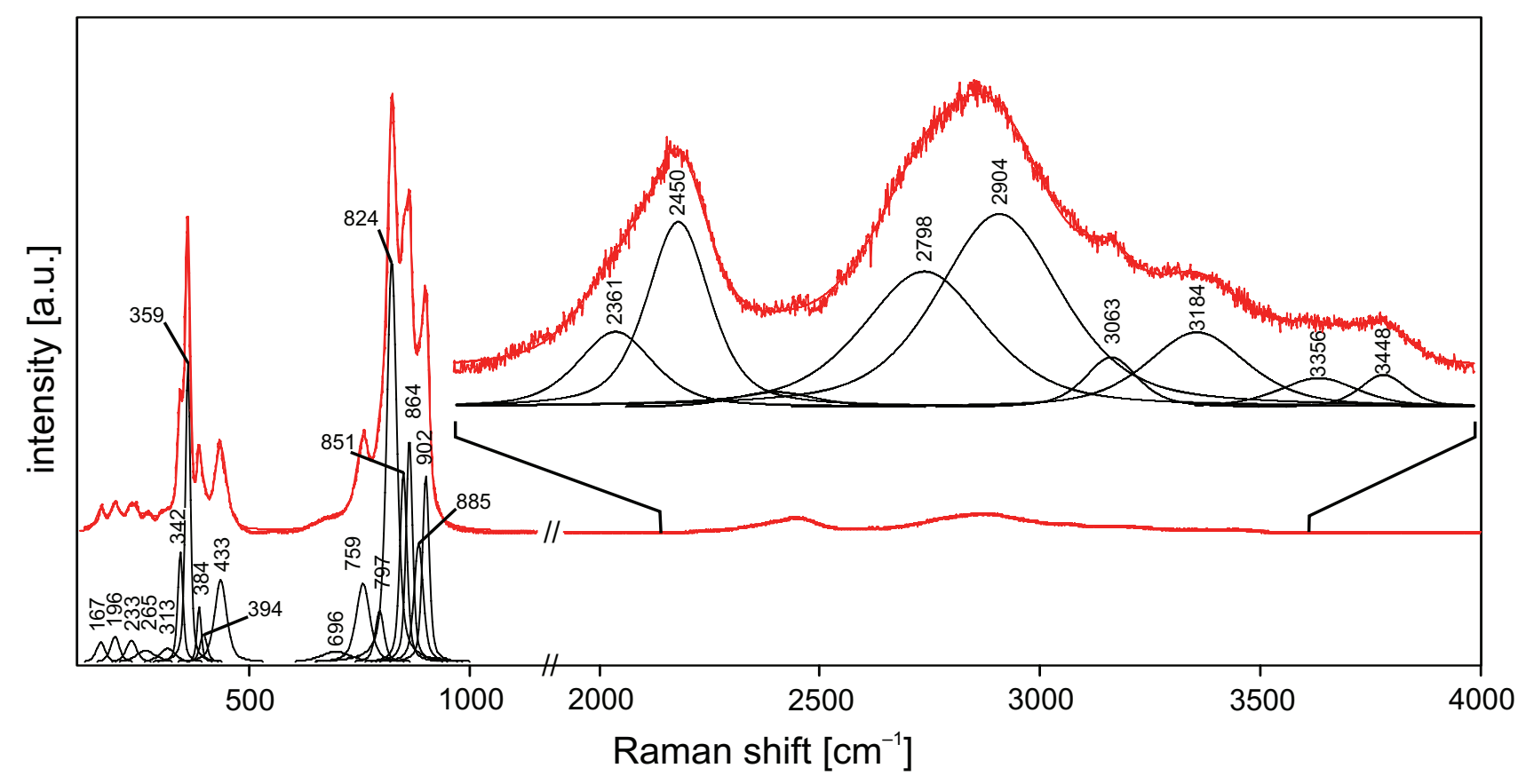

Fig. 2 The Raman spectrum of giftgrubeite. 
Tab. 2 Powder-diffraction data for giftgrubeite from Sainte-Marie-auxMines ( $d_{\mathrm{hkl}}$ values quoted in $\AA$ )

\begin{tabular}{lcccrll}
\hline$I_{\text {obs }} *$ & $d_{\text {obs }}$ & $I_{\text {calc }}$ & $d_{\text {calc }}$ & $h$ & $k$ & $l$ \\
\hline 20 & 9.35 & 24 & 9.19 & 2 & 0 & 0 \\
40 & 8.54 & 46 & 8.42 & 1 & 1 & 0 \\
10 & 6.68 & 17 & 6.60 & -1 & 1 & 0 \\
10 & 6.28 & 10 & 6.25 & 1 & 1 & 1 \\
50 & 4.80 & 14 & 4.76 & -3 & 1 & 1 \\
50 & 4.65 & 38 & 4.60 & -2 & 0 & 2 \\
40 & 4.43 & 35 & 4.39 & 3 & 1 & 1 \\
20 & 4.25 & 15 & 4.16 & 2 & 0 & 2 \\
30 & 4.01 & 17 & 3.95 & -2 & 2 & 1 \\
40 & 3.85 & 24 & 3.80 & 2 & 2 & 1 \\
30 & 3.46 & 21 & 3.43 & 0 & 2 & 2 \\
30 & 3.38 & 57 & 3.35 & -5 & 1 & 1 \\
100 & 3.33 & 100 & 3.30 & -2 & 2 & 2 \\
30 & 3.24 & 21 & 3.21 & -4 & 2 & 1 \\
80 & 3.18 & 68 & 3.13 & 2 & 2 & 2 \\
50 & 3.05 & 35 & 3.02 & 1 & 1 & 3 \\
20 & 2.78 & 14 & 2.74 & -3 & 3 & 1 \\
20 & 2.70 & 10 & 2.66 & 3 & 3 & 1 \\
50 & 2.488 & 15 & 2.479 & 0 & 0 & 4 \\
60 & 2.414 & 20 & 2.386 & 7 & 1 & 1 \\
\hline
\end{tabular}

* observed intensities might be affected by the preferred orientation effects

graphic parameters and data collection details are given in Tab. 3. Integration of the data, including corrections for background, polarization, and Lorentz effects, were carried out with the CrysAlis RED program. The absorption correction was finalized in the Jana2006 program (Petrríček et al. 2014). The giftgrubeite structure was solved by the charge-flipping algorithm using the SHELXT program (Sheldrick 2015) and subsequently refined by the leastsquares algorithm of the Jana2006 software (Petříček et al. 2014) based on $F^{2}$. Nearly all atom sites were found by the solution, missing positions of the remaining $\mathrm{O}$ atoms

a)

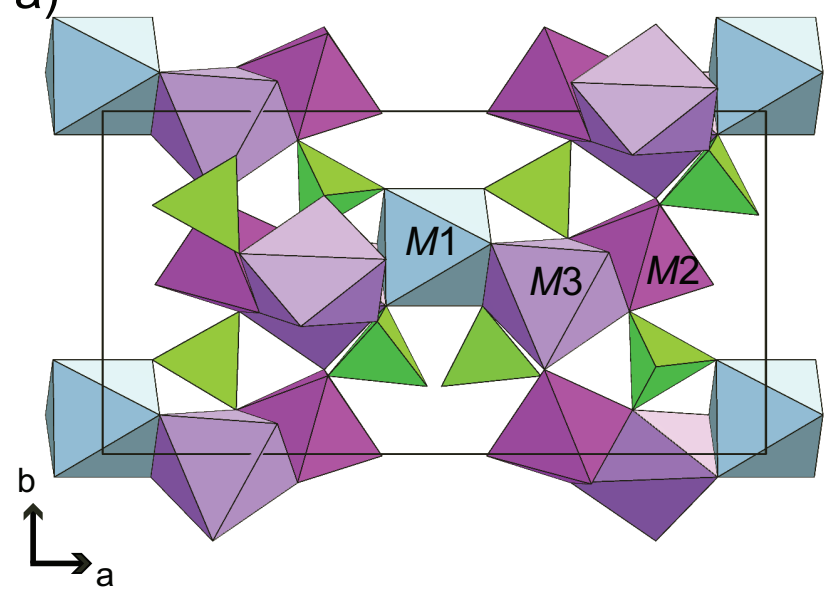

Tab. 3 Summary of data collection conditions, crystallographic details and structure refinement for giftgrubeite

\begin{tabular}{|c|c|}
\hline Structural formula & 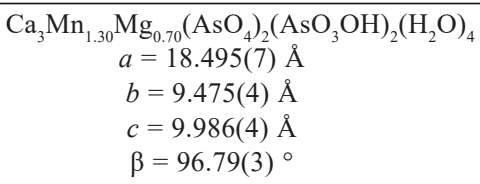 \\
\hline$V\left[\AA^{3}\right]$ & $1737.7(12)$ \\
\hline$Z$ & 4 \\
\hline Space group & $C 2 / c$ \\
\hline$D_{\text {calc. }}\left[\right.$ g. $\left.\mathrm{cm}^{-3}\right]$ & 3.205 (for the above given formula) \\
\hline Temperature & $282 \mathrm{~K}$ \\
\hline Wavelength & $\mathrm{Mo} K_{\alpha}, 0.71073 \AA$ \\
\hline Crystal dimensions & $46 \times 26 \times 21 \mu \mathrm{m}^{3}$ \\
\hline Limiting $\theta$ angles & $3.26-28.57^{\circ}$ \\
\hline Limiting Miller indices & $-24 \leq h \leq 22,-9 \leq k \leq 12,-8 \leq l \leq 13$ \\
\hline No. of reflections & 3398 \\
\hline No. of unique reflections & 1907 \\
\hline $\begin{array}{l}\text { No. of observed reflections } \\
\text { (criterion) }\end{array}$ & $542[I>3 \sigma(I)]$ \\
\hline $\begin{array}{l}\text { Absorption coefficient } \\
\left(\mathrm{mm}^{-1}\right), \text { method }\end{array}$ & 9.54 , analytical + empirical scaling \\
\hline $\mathrm{T}_{\min } / \mathrm{T}_{\max }$ & $0.783 / 0.885$ \\
\hline$R_{\text {int }}$ & 0.126 \\
\hline$F_{000}$ & 1572 \\
\hline $\begin{array}{l}\text { Parameters refined, } \\
\text { constraints, restraints }\end{array}$ & $133,9,0$ \\
\hline$R, w R$ (obs) & $0.0699,0.1634$ \\
\hline$R, \mathrm{w} R$ (all) & $0.2163,0.2610$ \\
\hline GOF (obs, all) & $1.22,0.99$ \\
\hline Weighting scheme & $1 /\left(\sigma^{2}(I)+0.0049000001 I^{2}\right)$ \\
\hline$\Delta \rho_{\min }, \Delta \rho_{\max }\left(\mathrm{e} . \AA^{-3}\right)$ & $-2.43,4.41$ \\
\hline
\end{tabular}

were located on the difference-Fourier maps. All atoms were refined using anisotropic displacement parameters, and the $M 2$ site was refined as a $\mathrm{Mn} / \mathrm{Mg}$ mixed site. Nevertheless, the refinement converged to somewhat higher $R$ values (Tab. 3) compared to e.g. refinement of structurally related miguelromeroite by Kampf (2009); the higher

b)

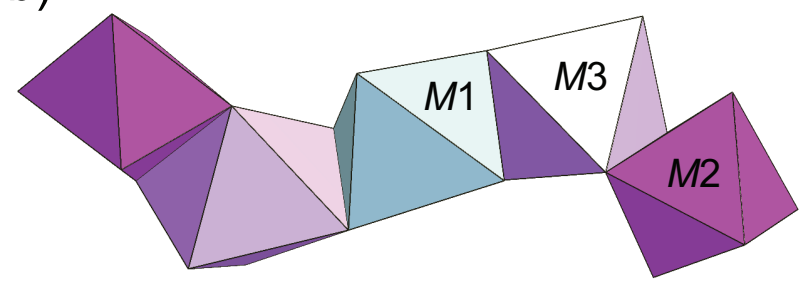

Fig. 3a - The crystal structure of giftgrubeite viewed down $c$. The As $s^{5+}$ tetrahedra are green, two Ca-based polyhedra are pale blue ( $\left.M 1\right)$ and lavender $(M 3), \mathrm{Mn} / \mathrm{Mg}$ polyhedra (M2) are pink. The unit-cell edges are displayed in solid black lines. For clarity, only half of the cell content along $c$ is shown. $\mathbf{b}$ - The pentamer of edge-sharing octahedra, which is characteristic of the hureaulite group of minerals. 
obtained $R$ values are namely due to weak signal caused by the poor quality of crystals. Atom coordinates, displacement parameters, and bond-valence sums (calculated by DIST procedure in Jana2006 using bond-valence parameters from Gagné and Hawthorne 2015) are listed in Tab. 4, anisotropic displacement parameters in supplementary Tab. $\mathrm{S} 1$ and selected interatomic distances are provided in Tab. 5. The original crystallographic information file (cif) for giftgrubeite is provided as Supplementary material and can be downloaded from the Journal web site http://jgeosci.org.
Tab. 4 Atom positions and equivalent displacement parameters $\left(U_{\text {eq }}\right.$, in $\left.\AA^{2}\right)$ for giftgrubeite

\begin{tabular}{|c|c|c|c|c|c|c|}
\hline$\# 1$ & & & & & & \\
\hline Atom & $O c c$. & $x / a$ & $y / b$ & $z / c$ & $U_{\text {eq/iso }}$ & $B V$ \\
\hline As1 & & $0.66020(13)$ & $0.7682(3)$ & $0.6221(2)$ & $0.0325(8)$ & $5.2(1)$ \\
\hline As2 & & $0.58408(13)$ & $0.6878(3)$ & $0.0894(2)$ & $0.0335(9)$ & $5.3(1)$ \\
\hline$M 1$ & & 0.5 & $0.3891(7)$ & 0.25 & $0.029(2)$ & $2.20(4)$ \\
\hline$M 2$ & $0.65(2) / 0.35(2)$ & $0.6840(2)$ & $0.9164(5)$ & $0.3139(4)$ & $0.0330(17)$ & $1.79(3)$ \\
\hline$M 3$ & & $0.6756(3)$ & $0.4689(5)$ & $0.8613(4)$ & $0.0343(17)$ & $2.04(4)$ \\
\hline $\mathrm{O} 1$ & & $0.7367(8)$ & $1.0882(16)$ & $0.4706(14)$ & $0.037(6)$ & $0.46(1)$ \\
\hline $\mathrm{O} 2$ & & $0.5749(8)$ & $0.7743(16)$ & $0.6478(14)$ & $0.035(5)$ & $1.78(6)$ \\
\hline $\mathrm{O} 3$ & & $0.6660(8)$ & $0.7541(16)$ & $0.4548(13)$ & $0.031(5)$ & $1.95(7)$ \\
\hline $\mathrm{O} 4$ & & $0.7061(9)$ & $0.9158(16)$ & $0.6754(14)$ & $0.041(6)$ & $1.93(7)$ \\
\hline O5 & & $0.6606(8)$ & $0.7724(17)$ & $0.1412(15)$ & $0.038(6)$ & $1.68(6)$ \\
\hline $\mathrm{O} 6(\mathrm{OH})$ & & $0.5108(9)$ & $0.803(2)$ & $0.0793(15)$ & $0.052(7)$ & $1.09(5)$ \\
\hline O7 & & $0.7013(9)$ & $0.6281(17)$ & $0.7005(16)$ & $0.048(6)$ & $1.99(7)$ \\
\hline O8 & & $0.5859(8)$ & $0.6135(17)$ & $-0.0604(14)$ & $0.037(6)$ & $2.07(5)$ \\
\hline O9 & & $0.5790(10)$ & $1.006(2)$ & $0.3325(16)$ & $0.052(7)$ & $0.35(1)$ \\
\hline $\mathrm{O} 10$ & & $0.5728(8)$ & $0.5678(18)$ & $0.2018(14)$ & $0.042(6)$ & $2.24(7)$ \\
\hline
\end{tabular}

In giftgrubeite $M 1$ and $M 3$ site are occupied by $\mathrm{Ca}^{2+}, M 2$ is a mix $\mathrm{Mn} / \mathrm{Mg}$ site.

\subsection{General crystal-structure features}

The structure of giftgrubeite (Fig. 3a) is a well-known type of the hureaulite group of minerals (Ferraris and Abona 1972; Moore and Araki 1973; Kampf 2009). The fundamental building block that these minerals contain is an octahedral edge-sharing pentamer (Fig. 3b). Pentamers are linked into a loose framework by sharing corners with octahedra in adjacent pentamers, and they are further linked via $\mathrm{AsO}_{4}$ and $\mathrm{AsO}_{3} \mathrm{OH}$ tetrahedra. There are three distinct octahedral sites designated $M 1, M 2$, and $M 3$ (Tab. 4; Fig. 3a-b). In the case of giftgrubeite two of the $M$ sites were found to be fully occupied by $\mathrm{Ca}^{2+}$ (M1 and $M 3$ sites). The $M 2$ site is occupied by $\mathrm{Mg}^{2+}$ additionally to the dominant $\mathrm{Mn}^{2+}$. The site-scattering refinements provided fractions of $0.35(2) \mathrm{Mg}$ (crystal $\# 1$ ) and $0.29(2) \mathrm{Mg}$ (crystal \#2) at the $M 2$ site, giving 0.70 and $0.58 \mathrm{Mg}$ apfu, respectively. The presence of $\mathrm{Fe}$, documented by the electron-microprobe study, was, however, neglected in the refinement, namely due to the increased number of parameters against the poorer data quality. The $\mathrm{Mg}$ content obtained from the refinement is then a result of a combination of $(\mathrm{Mg}+\mathrm{Fe})$ mixing at the site. The average $<M 2-\Phi>$ bond-length of 2.20 and $2.21 \AA$, respectively, corresponds well with the $\mathrm{Mn}-\mathrm{O}$ distances observed in the Mn-dominant member of the hureaulite group, miguelromeroite (Kampf 2009). Considering the refined site occupancies, the structural formula for giftgrubeite is $\mathrm{Ca}_{3} \mathrm{Mn}_{1.30} \mathrm{Mg}_{0.70}$ $\left(\mathrm{AsO}_{4}\right)_{2}\left(\mathrm{AsO}_{3} \mathrm{OH}\right)_{2}\left(\mathrm{H}_{2} \mathrm{O}\right)_{4}$ (crystal $\left.\# 1\right)$, for $Z=4$. This formula in line with the empirical formula obtained from the electron microprobe; however, we were not able to distinguish between $\mathrm{Mg}$ and $\mathrm{Fe}$ in our structure refinement.
Tab. 5 Selected interatomic distances (in $\AA$ ) in the giftgrubeite structure

\begin{tabular}{|c|c|c|c|}
\hline$\# 1$ & & & \\
\hline As1-O2 & $1.63(2)$ & As2-O5 & $1.65(2)$ \\
\hline As1-O3 & $1.69(1)$ & As2-O6(OH) & $1.73(2)$ \\
\hline As1-O4 & $1.69(2)$ & As2-O8 & $1.65(1)$ \\
\hline As1-O7 & $1.68(2)$ & As2-O10 & $1.63(2)$ \\
\hline$<$ As $1-\mathrm{O}>$ & 1.67 & $<$ As2-O $>$ & 1.68 \\
\hline$M 1-\mathrm{O} 2^{\mathrm{iii}}$ & $2.38(2)$ & & \\
\hline$M 1-\mathrm{O} 2^{\mathrm{iv}}$ & $2.38(2)$ & & \\
\hline$M 1-\mathrm{O}^{\mathrm{v}}$ & $2.33(2)$ & & \\
\hline$M 1-\mathrm{O} 8^{\mathrm{vi}}$ & $2.33(1)$ & & \\
\hline M1-O10 & $2.25(2)$ & & \\
\hline$M 1-\mathrm{O} 10^{\mathrm{vii}}$ & $2.25(2)$ & & \\
\hline$<M 1-\mathrm{O}>$ & 2.32 & & \\
\hline$\overline{M 2-\mathrm{O} 1}$ & $2.39(2)$ & $M 3-\mathrm{O} 1^{\text {viii }}$ & $2.46(1)$ \\
\hline$M 2-\mathrm{O} 3$ & $2.14(2)$ & $M 3-\mathrm{O} 3^{\mathrm{vi}}$ & $2.33(2)$ \\
\hline$M 2-\mathrm{O} 4^{\mathrm{i}}$ & $2.18(2)$ & $M 3-\mathrm{O} 4^{\mathrm{viii}}$ & $2.32(2)$ \\
\hline$M 2-\mathrm{O} 5$ & $2.21(2)$ & M3-O7 & $2.29(2)$ \\
\hline$M 2-\mathrm{O} 7^{\mathrm{ii}}$ & $2.19(2)$ & $M 3-\mathrm{O}^{\mathrm{ix}}$ & $2.36(2)$ \\
\hline M2-O9 & $2.15(2)$ & $M 3-\mathrm{O} 10^{\mathrm{vi}}$ & $2.36(1)$ \\
\hline$<M 2-\mathrm{O}>$ & 2.21 & $<M 3-\mathrm{O}>$ & 2.35 \\
\hline
\end{tabular}

Symmetry codes: (i) $x,-y+2, z-1 / 2$; (ii) $-x+3 / 2,-y+3 / 2,-z+1$; (iii) $x+1,-y+1,-z+1$; (iv) $x,-y+1, z-1 / 2$; (v) $-x+1,-y+1,-z$; (vi) $x,-y+1$, $z+1 / 2$; (vii) $-x+1, y,-z+1 / 2$; (viii) $-x+3 / 2, y-1 / 2,-z+3 / 2$; (ix) $x, y, z+1$.

\section{Discussion}

\subsection{Giftgrubeite and other As-bearing members of the hureaulite group}

Giftgrubeite is a new member of the hureaulite group of minerals, structurally closely related to As-members of the group: miguelromeroite, $\mathrm{MnMn}_{2} \mathrm{Mn}_{2}\left(\mathrm{AsO}_{3} \mathrm{OH}\right)_{2}\left(\mathrm{AsO}_{4}\right)_{2} \cdot 4 \mathrm{H}_{2} \mathrm{O}$ (Kampf 2009), villyaellenite, $\mathrm{MnMn}_{2} \mathrm{Ca}_{2}\left(\mathrm{AsO}_{3} \mathrm{OH}\right)_{2}\left(\mathrm{AsO}_{4}\right) 2 \cdot 4 \mathrm{H}_{2} \mathrm{O}(\mathrm{Kampf}$ 
Tab. 6 Comparative data for the members of the hureaulite group of minerals

\begin{tabular}{|c|c|c|c|c|}
\hline $\begin{array}{l}\text { type locality } \\
\text { reference }\end{array}$ & $\begin{array}{c}\text { giftgrubeite } \\
\text { Sainte-Marie-aux-Mines, France } \\
\text { this paper }\end{array}$ & $\begin{array}{c}\text { villyaellenite } \\
\text { Sainte-Marie-aux-Mines, France } \\
\text { Sarp (1984), Kampf (2009) }\end{array}$ & $\begin{array}{c}\text { miguelromeroite } \\
\text { Ojuela mine, Mexico } \\
\text { Kampf (2009) }\end{array}$ & $\begin{array}{c}\text { sainfeldite } \\
\text { Sainte-Marie-aux-Mines, France } \\
\text { Pierrot (1964), } \\
\text { Ferraris and Abona (1972) }\end{array}$ \\
\hline$M 1(1 a p f u)$ & $\mathrm{Ca}$ & $\mathrm{Mn}, \mathrm{Ca}$ & $\mathrm{Mn}$ & $\mathrm{Ca}$ \\
\hline$M 2(2$ apfu $)$ & $\mathrm{Ca}$ & $\mathrm{Mn}$ & $\mathrm{Mn}$ & $\mathrm{Ca}$ \\
\hline M3 (2 apfu) & $\mathrm{Mn}$ & $\mathrm{Ca}$ & $\mathrm{Mn}$ & $\mathrm{Ca}$ \\
\hline Me (ideal.) & $\mathrm{Ca}_{2} \mathrm{CaMn}_{2}$ & $\mathrm{Mn}_{3} \mathrm{Ca}_{2}$ & $\mathrm{Mn}_{5}$ & $\mathrm{Ca}_{5}$ \\
\hline$M e$ (meas.) & $\mathrm{Ca}_{3.04} \mathrm{Mn}_{1.30} \mathrm{Mg}_{0.38} \mathrm{Fe}_{0.28}$ & $\left(\mathrm{Mn}_{2.69} \mathrm{Ca}_{2.07}\right)_{\sum 4.76}$ & $\mathrm{Mn}_{4.63} \mathrm{Zn}_{0.32} \mathrm{Ca}_{0.08} \mathrm{Fe}_{0.01}$ & $\mathrm{Ca}_{5}$ \\
\hline space group & $C 2 / c$ & $C 2 / c$ & $C 2 / m$ & $C 2 / m$ \\
\hline $\mathrm{a}$ & $18.495(7)$ & $18.400(2)$ & $18.030(1)$ & $18.781(7)$ \\
\hline $\mathrm{b}$ & $9.475(4)$ & $9.4778(10)$ & $9.2715(5)$ & $9.820(4)$ \\
\hline $\mathrm{c}$ & $9.986(4)$ & $9.9594(12)$ & $9.7756(5)$ & $10.191(4)$ \\
\hline$\beta$ & $96.79(3)$ & $96.587(3)$ & $96.266(2)$ & $97.02(3)$ \\
\hline$V$ & $1737.7(12)$ & $1725.4(3)$ & $1624.4(2)$ & 1865.4 \\
\hline Z & 4 & 4 & 4 & 4 \\
\hline$R_{\mathrm{obs},} R_{\mathrm{all}}(\%)$ & $6.99 / 21.63$ & $10.26 / 12.33$ & $3.83 / 4.02$ & 3.90 \\
\hline strongest lines & $8.54 / 40$ & $8.476 / 90$ & $8.279 / 28$ & 8.7 \\
\hline \multirow[t]{2}{*}{ in XRD } & $4.80 / 50$ & $4.761 / 40$ & $3.734 / 15$ & 4.86 \\
\hline & $4.65 / 50$ & $4.606 / 50$ & $3.357 / 33$ & 4.64 \\
\hline powder pattern & $3.33 / 100$ & $3.811 / 40$ & $3.234 / 100$ & 4.45 \\
\hline \multirow[t]{2}{*}{$\left(d \AA / I_{\mathrm{obs}}\right)$} & $3.18 / 80$ & $3.297 / 100$ & $3.074 / 68$ & $3.37 / 100$ \\
\hline & $3.05 / 50$ & $3.132 / 60$ & $2.97 / 39$ & $3.18 / 50$ \\
\hline
\end{tabular}

$2009)$ sainfeldite, $\mathrm{CaCa}_{2} \mathrm{Ca}_{2}\left(\mathrm{AsO}_{4}\right)_{2}\left(\mathrm{AsO}_{3} \mathrm{OH}\right)_{2} \cdot 4 \mathrm{H}_{2} \mathrm{O}$ (Ferraris and Abona 1972), and chongite $\mathrm{CaMg}_{2} \mathrm{Ca}_{2}\left(\mathrm{AsO}_{4}\right)_{2}\left(\mathrm{AsO}_{3} \mathrm{OH}\right)_{2} \cdot 4 \mathrm{H}_{2} \mathrm{O}$ (Kampf et al. 2015). Comparative data for these species are presented in Tab. 6. Giftgrubeite, $\mathrm{CaMn}_{2} \mathrm{Ca}_{2}\left(\mathrm{AsO}_{4}\right)_{2}\left(\mathrm{AsO}_{3} \mathrm{OH}\right)_{2} \cdot 4 \mathrm{H}_{2} \mathrm{O}$ is an ordered intermediate member between villyaellenite, $\mathrm{MnMn}_{2} \mathrm{Ca}_{2}\left(\mathrm{AsO}_{3} \mathrm{OH}\right)_{2}\left(\mathrm{AsO}_{4}\right) 2 \cdot 4 \mathrm{H}_{2} \mathrm{O}$, and sainfeldite, $\mathrm{CaCa}_{2} \mathrm{Ca}_{2}\left(\mathrm{AsO}_{3} \mathrm{OH}\right)_{2}\left(\mathrm{AsO}_{4}\right) 2 \cdot 4 \mathrm{H}_{2} \mathrm{O}$, and corresponds to the unnamed mineral phase mentioned by
Kampf (2009) from Gozaisho Mine in Japan. As noted by Kampf (2009) the $M 1$ site is capable of accepting a full range of $\mathrm{Ca}$ and $\mathrm{Mn}$ occupancies. The $\mathrm{M} 2$ site is then capable of accepting a distinct proportion of $\mathrm{Mn}$, $\mathrm{Mg}$ and $\mathrm{Ca}$ occupancies, leading to end-members: giftgrubeite $(\mathrm{Mn})$, chongite $(\mathrm{Mg})$ and sainfeldite $(\mathrm{Ca})$. The $\mathrm{Mg}$ content in giftgrubeite corresponds to chongite component; its presence suggests that at least a limited solid-solution between these two end-members exists and Mn-chongite, with atomic ratio $\mathrm{Ca}: \mathrm{Mg}: \mathrm{Mn}=66: 19: 16$ was observed intimately associated with giftgrubeite. Noteworthy, the substitutions that take place in the structure of giftgrubeite and related As-bearing members of the hureaulite group, lead to an increasing unit-cell volume with an increasing portion of $\mathrm{Ca}^{2+}$ entering the structure (Fig. 4). The [6]-coordinated $\mathrm{Ca}^{2+}$ is larger $(1 \AA)$ than [6]-coordinated $\mathrm{Mn}^{2+}(0.83 \AA)$, while considering their ionic radii (Shannon 1976).

Fig. 4 Dependence of the unit-cell volume on the fraction of $\mathrm{Ca}^{2+}$ in the structures of As-bearing members of the hureaulite group of minerals. 


\subsection{Formation of giftgrubeite}

Careful micro- and macroscopic study of the giftgrubeite mineral association showed that the new mineral formed via atmospheric oxidation weathering of native arsenic in the wet environment of the abandoned mine. The formation involves several steps. The first is represented by oxidation weathering of massive or disseminated native arsenic to arsenic (III) oxide, $\mathrm{As}_{2} \mathrm{O}_{3}$, which is thermodynamically favored (Majzlan et al. 2014). $\mathrm{As}_{2} \mathrm{O}_{3}$ in contact with humid air or oxygen-rich descending (meteoric) water subsequently oxidizes into highly hygroscopic arsenic $(\mathrm{V})$ oxide, $\mathrm{As}_{2} \mathrm{O}_{5}$, dissolves and this leads to the formation of solutions containing various arsenate anion species, depending on corresponding $\mathrm{pH}$ (in an increasing order), e.g.: $\mathrm{H}_{2} \mathrm{AsO}_{4}{ }^{-}, \mathrm{HAsO}_{4}{ }^{2-}, \mathrm{AsO}_{4}{ }^{3-}$ or $\left(\mathrm{AsO}_{3} \mathrm{OH}\right)^{2-}$ (see Pierrot 1964; Majzlan et al. 2014). Such solutions then attack gangue carbonates, here mostly the $\mathrm{Mn}-\mathrm{Fe}-$ bearing calcite and dolomite, which proceeds with the shift in $\mathrm{pH}$ to more alkaline (see model 3Aa of Markl et al. 2014), and subsequent formation of giftgrubeite (as the main $\mathrm{Ca}-\mathrm{Mn}$-bearing arsenate) and picropharmacolite (as the main Mg-bearing arsenate) from locally oversaturated solutions.

Acknowledgements. We are glad for comments made by two referees, Anthony R. Kampf and Oleg Siidra as well as those by handling editor František Laufek that helped us improving the manuscript. The research was financially supported by the Czech Science Foundation (project GACR 17-09161S) for JP and by MUNI/A/1653/2016 for RS.

Electronic supplementary material. Supplementary crystallographic data and table of anisotropic displacement parameters in giftgrubeite is available online at the Journal web site (http://dx.doi.org/10.3190/ jgeosci.276).

\section{References}

Bari H, Permingeat F, Pierrot R, Walenta K (1980a) La ferrarisite, $\mathrm{Ca}_{5} \mathrm{H}_{2}\left(\mathrm{AsO}_{4}\right)_{4} \cdot 9 \mathrm{H}_{2} \mathrm{O}$, une nouvelle espèce minérale isomorphe de la guérinite. Bull Soc franc Minéral Cristallogr 103: 533-540

Bari H, Cesbron F, Permingeat F, Pillard F (1980b) La fluckite, arséniate hydraté de calcium et manganèse, $\mathrm{CaMnH}_{2}\left(\mathrm{AsO}_{4}\right)_{2} \cdot 2 \mathrm{H}_{2} \mathrm{O}$, une nouvelle espèce minérale. Bull Soc franc Minéral Cristallogr 103: 122-128

Bari H, Catti M, Ferraris G, Ivaldi G, Permingeat F (1982) Phaunouxite, $\mathrm{Ca}_{3}\left(\mathrm{AsO}_{4}\right)_{2} \cdot 11 \mathrm{H}_{2} \mathrm{O}$, a new mineral strictly associated with rauenthalite. Bull Soc franc Minéral Cristallogr 105: 327-332
Ferraris G, AbBona F (1972) The crystal structure of $\mathrm{Ca}_{5}\left(\mathrm{HAsO}_{4}\right)_{2}\left(\mathrm{AsO}_{4}\right)_{2} \cdot 4 \mathrm{H}_{2} \mathrm{O}$ (sainfeldite). Bull Soc franc Minéral Cristallogr 95: 33-41

GAGNÉ OC, HAWTHORNE FC (2015) Comprehensive derivation of bond-valence parameters for ion pairs involving oxygen. Acta Crystallogr B71: 562-578

Hålenius U, Hatert F, Pasero M, Mills S J (2017) New minerals and nomenclature modifications approved in 2017, CNMNC, NEWSLETTER 36. Mineral Mag 81: 403-409

Herpin P, Pierrot R (1963) La weilite, $\mathrm{CaH}\left(\mathrm{AsO}_{4}\right)$, un nouvel arséniate de calcium isomorphe de la monétite. Bull Soc franc Minéral Cristallogr 86: 368-372

HOLLAND T, REDFERN SAT (1997) Unit cell refinement from powder diffraction data: the use of regression diagnostics. Mineral Mag 61: 65-77

KAMPF AR (2009) Miguelromeroite, the Mn analogue of sainfeldite, and redefinition of villyaellenite as an ordered intermediate in the sainfeldite-miguelromeroite series. Amer Miner 94: 1535-1540

Kampf AR, Nash B, Dini M, Molina Donoso AA (2015) Chongite, $\mathrm{Ca}_{3} \mathrm{Mg}_{2}\left(\mathrm{AsO}_{4}\right)_{2}\left(\mathrm{AsO}_{3} \mathrm{OH}\right)_{2} \cdot 4 \mathrm{H}_{2} \mathrm{O}$, a new arsenate member of the hureaulite group from the Torrecillas Mine, Iquique Province, Chile. Mineral Mag 80: $1255-1263$

Majzlan J, PlášIl J, Š́oda R, Gescher J, Kögler F, Rusznyak A, Küsel K, Neu TR, Mangold S, Rothe J (2014) Arsenic-rich acid mine water with extreme arsenic concentration: mineralogy, geochemistry, microbiology, and environmental implications. Environ Sci Technol 48: 13685-13693

Markl G, Marks MAW, Derrey I, GüHring J-E (2014) Weathering of cobalt arsenides: natural assemblages and calculated stability relations among secondary $\mathrm{Ca}-\mathrm{Mg}-$ Co arsenates and carbonates. Amer Miner 99: 44-56

MERLET C (1994) An accurate computer correction program for quantitative electron probe microanalysis. Microchim Acta 114/115: 363-376

Moore PB, Araki T (1973) Hureaulite, $\mathrm{Mn}^{2+}{ }_{5}\left(\mathrm{H}_{2} \mathrm{O}\right)_{4}$ $\left[\mathrm{PO}_{3}(\mathrm{OH})\right]_{2}\left[\mathrm{AsO}_{4}\right]_{2}:$ its atomic arrangement. Amer Miner 58: 302-307

Petř́íček V, Dušek M, Palatinus L (2014) Crystallographic Computing System Jana2006: general features. Z Kristallogr 229: 345-352

Pierrot R (1964) Contribution à la minéralogie des arséniates calciques et calcaromagnésiens naturels. Bull Soc franc Minéral Cristallogr 87: 169-211

SARP H (1984) Villyaellenite, $\mathrm{H}_{2}(\mathrm{Mn}, \mathrm{Ca})_{5}\left(\mathrm{AsO}_{4}\right)_{4} \cdot 4 \mathrm{H}_{2} \mathrm{O}$ un nouveau mineral de Sainte-Marie aux-Mines (France). Schweiz mineral petrogr Mitt 64: 323-328

Sarp H, Deferne J, Liebich BW (1981) La mcnéarite, $\mathrm{NaCa}_{5} \mathrm{H}_{4}\left(\mathrm{AsO}_{4}\right)_{5} \cdot 4 \mathrm{H}_{2} \mathrm{O}$, un nouvel arséniate hydraté de calcium et de sodium. Schweiz mineral petrogr Mitt 61: $1-6$ 
SHANNON RD (1976) Revised effective ionic radii and systematic studies of interatomic distances in halides and chalcogenides. Acta Crystallogr A32: 751-767
SHELDRICK GM (2015) SHELXT - integrated space-group and crystal-structure determination. Acta Crystallogr A71: 3-8 